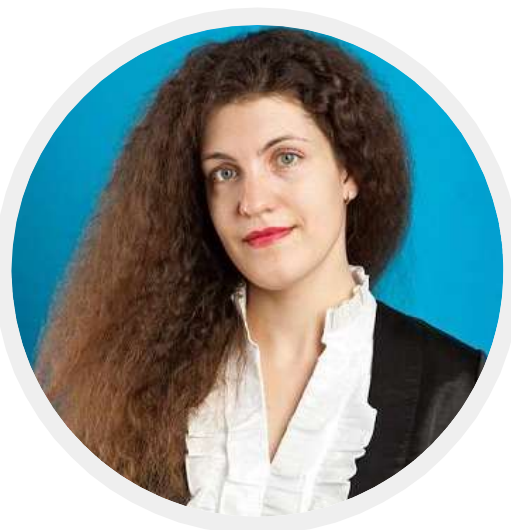

\title{
Олена Олькіна
}

кандидат юридичних наук,

доцент кафедри конституційного права Національного університету «Одеська юридична академія»,

\section{КОНСТИТУЦЙНО-ПРАВОВА ПРИРОДА ВИБОРЧИХ КОМІСІЙ ЗА СТАНДАР- ТАМИ ЄВРОПЕЙСЬКОЇ МОДЕЛІ КОНСТИТУЦОНАЛІЗМУ \\ THE CONSTITUTIONAL AND LEGAL NATURE OF THE ELECTION COMMISSIONS ACCORDING TO THE STANDARDS OF THE EUROPEAN MODEL OF CONSTITUTIONALISM}

\section{Olena Olkina}

\author{
National University "Odessa Law Academy", Ukraine
}

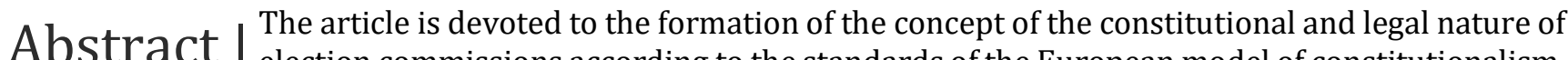
Abstract $\mid$ election commissions according to the standards of the European model of constitutionalism, formed by the Venice Commission. The organizational and legal form of the election commission as a legal entity of public law, an independent state-government institution with a representative character that can form the electoral power, and a temporary nature of functioning for territorial and district election commissions is characterized. The interaction of election commissions with the system of executive power in Ukraine is considered. The sign of independence of election commissions is analyzed, which is manifested in the special order of formation of their personal composition and early termination of the powers of their individual members, as well as in the presence of independent powers of authority and material and financial independence. The signs of collegiality, which is implemented in the order of decision-making by election commissions, are investigated and should be supported by two-thirds of the members of the relevant commission; competence consisting in special legal knowledge and practical skills in execution of the electoral process, the establishment of stricter qualification requirements for members of the Central Election Commission; transparency and openness.

The challenging issues of ensuring the independence of election commissions have been identified and suggestions have been developed on the prospective directions for improving the constitutional and legal status of electoral commissions in Ukraine, in particular the procedure for the formation of the personal composition of the Central Election Commission by representatives of various branches of power and expansion of its powers with the aim of forming a separate branch of the electoral power, as well as improvement of the constitutional and legal regulation of the practical activities of other electoral commissions.
\end{abstract}

Keywords: elections, election subjects, election commission, electoral power, organization and holding the elections. 
Анотація | $\begin{aligned} & \text { Статтю присвячено формуванню концепту конституційно-правової природи вибо- } \\ & \text { рчих комісій за стандартами європейської моделі конституціоналізму, сформова- }\end{aligned}$ ними Венеціанською комісією. Охарактеризовано організаційно-правову форму виборчої комісії як юридичної особи публічного права, самостійного державно-владного інституту з представницьким характером, що може формувати виборчу владу, та тимчасовим характером функціонування для окружних (територіальних) і дільничних виборчих комісій. Розглянуто взаємодію виборчих комісій з системою виконавчої влади в Україні. Проаналізовано ознаку незалежності виборчих комісій, що проявляється в особливому порядку формування їх персонального складу та дострокового припинення повноважень окремих їх членів, а також у наявності самостійних владних повноважень і матеріально-фінансової самостійності. Досліджено ознаки: колегіальності, яка втілюється в порядку прийняття рішень виборчими комісіями та повинна бути підтримана двома третинами членів відповідної комісії; компетентності, що полягає в особливих юридичних знаннях та практичних навичках здійснення виборчого процесу, встановленні підвищених кваліфікаційних вимог до членів Центральної виборчої комісії; прозорості та відкритості.

Виявлено проблемні аспекти забезпечення незалежності виборчих комісій та розроблено пропозиції щодо перспективних напрямів вдосконалення конституційно-правового статусу виборчих комісій в Україні, зокрема порядку формування персонального складу Центральної виборчої комісії представниками різних гілок (галузей) влади та розширення ії повноважень з метою формування окремої гілки (галузі) виборчої влади, а також вдосконалення конституційно-правового регулювання практичної діяльності виборчих комісій нижчого рівня.

Ключові слова: вибори, суб’єкти виборчого процесу, виборчі комісії, виборча влада, організація й проведення виборів.

Розвиток демократії в Україні неможливий без проведення виборів представницьких органів державної влади та місцевого самоврядування. У цьому процесі найважливішу роль відіграє відтворення відповідності волі виборців у офіційно проголошених результатах виборів, що повинно забезпечуватися діяльністю спеціальних суб'єктів - виборчих комісій різних рівнів.

Однак сучасна вітчизняна виборча практика свідчить про те, що з боку різних політичних сил та державних інститутів відбуваються спроби незаконно вплинути на результат виборів та функціонування виборчих комісій. Крім того, триваюча реформа виборчого законодавства, його кодифікація та уніфікація правових норм щодо статусу виборчих комісій актуалізує переосмислення їхьої природи та ролі в організаційному механізмі народовладдя в Україні, що дозволить вирішити ряд проблем, пов'язаних з діяльністю виборчих комісій під час організації проведення виборів та референдумів.

Дослідженням функціонування виборчих комісій в Україні займалися такі науковці як Н. Богашева, М. Бучин, А. Войцеховська, Ю. Ключковський, Л. Козодой, К. Осадчук, І. Тимошенко та інші. У працях названих авторів висвітлено окремі аспекти формування виборчих комісій, їхніх повноважень та відповідальності, але проблема визначення конституційно-правової природи виборчих комісій повністю не вирішена. Крім того, залишається відкритим питання відповідності статусу виборчих комісій в Україні стандартам європейської моделі конституціоналізму, а також закріплення механізмів забезпечення незалежності та неупередженості у діяльності виборчих комісій.

Мета даної статті полягає у формуванні цілісної концепції конституційно-правової природи виборчих комісій за стандартами європейської моделі конституціоналізму та вдосконаленні конституційно-правового регулювання їхнього функціонування для забезпечення демократичності проведення виборів в Україні.

Варто погодитись з О.М. Бориславською у тому, що «Венеційська комісія відіграла важливу роль у просуванні тих принципів, які лежать в основі функціонування Ради Європи, та суттєво вплинула на розвиток європейської моделі конституціоналізму. Хоча їі акти формально не мають обов'язкової сили, проте вони суттєво впливають на приведення національних конституційних 
систем до рівня європейських стандартів прав людини, демократії та верховенства права. Сила актів Венеційської комісії значною мірою зумовлена її авторитетом, що підтримується не тільки статутними органами Ради Європи, але й Європейського Союзу»1. Саме тому ключовими орієнтирами для визначення конституційно-правової природи виборчих комісій в Україні з урахування стандартів європейської моделі конституціоналізму мають бути документи Венеційської комісії.

Концептуалізація конституційно-правової природи виборчих комісій зумовлює необхідність виокремлення та проведення аналізу наскрізних сутнісних ознак, що відрізняють їх від інших суб’єктів конституційних правовідносин, які відповідають за динаміку європейської моделі конституціоналізму.

Першою ознакою, яка визначає конституційно-правову природу виборчих комісій, $\epsilon$ їхня організаційно-правова форма.

Традиційно комісії відносяться до колективних суб'єктів права. Виходячи зі змісту запропонованого О.А. Паращевіною визначення колективного суб'єкта права як «правової особи з колективною правовою формою організації, що набуває правосуб'єктності з моменту її визнання або реєстрації, засновниками (учасниками) якої можуть бути фізичні і юридичні особи, соціальні спільноти та їх об'єднання»2, можна зробити висновок, що виборчі комісії є правовими особами. Однак категорія «правові особи» не є усталеною ні в юридичній науці, ні в чинному законодавстві.

В.Д. Яворський визначає колективні суб’єкти виборчого права як «організовані, відокремлені групи громадян, наділені правами виступати у виборчих правовідносинах єдиною персоніфікованою спільнотою»3. На думку Л.М. Козодоя, суб’єктом виборчого процесу в Україні, зокрема, $\epsilon$ «колектив людей, який утворений відповідно до законодавства, має певну організаційну структуру, здатну виявляти єдину волю та визначати мету своєї діяльності, пов'язану з реалізацією свого активного чи пасивного виборчого права або забезпечувати реалізацію виборчого права іншими суб’єктами виборчого процесу і яка може вступати в правові відносини як єдина особа (фізична чи юридична), наділена законодавством виборчо-процесуальною правоздатністю, дієздатністю та деліктоздатністю».

Зі змісту наведених позицій можна виділити спільні властивості колективних суб'єктів виборчих правовідносин, у тому числі і виборчих комісій (створених у встановленому чинним законодавством України порядку; фіксований характер участі, організаційна єдність, наявність специфічних функцій, обумовлених метою створення), які характеризують їх як юридичних осіб.

Крім того, Центральна виборча комісія є юридичною особою на підставі частини третьої статті 1 Закону «Про Центральну виборчу комісію». Статус юридичної особи мають окружні комісії загальнонаціональних виборів (частина четверта статті 22 Закону «Про вибори Президента України»6, частина п'ята статті 25 Закону «Про вибори народних депутатів України»7). Водночас дільничні виборчі комісії, утворені під час будь-яких виборів, не мають статусу юридичної особи.

За твердженням Н. Богашевої та Ю. Ключковського «статус юридичної особи для виборчої комісії як цивільно-правовий є допоміжним порівняно з їі основним - публічно-правовим статусом як державного органу. Він лише забезпечує участь виборчої комісії у цивільному обігу, надаючи

\footnotetext{
${ }^{1}$ Бориславська О. М. Вплив Ради Європи та Європейського Союзу на формування європейської (континентальної) моделі конституціоналізму. Правова держава.2016. №24. С. 46.

2 Паращевіна О.А. Деякі проблеми класифікації колективних суб’єктів права. Актуальні проблеми держави і права. 2011. № 62. С. 651-658.

3 Яворський В.Д. Суб'єкти виборчого права України: поняття, ознаки та їх види. Державне будівництво та місцеве самоврядування. 2002. № 4. С. 48.

4 Козодой Л.М. Конституційно-правовий статус суб'єктів виборчого процесу в Україні : дис... канд. юрид. наук : 12.00 .02$. 2006. С. 68.

5 Про Центральну виборчу комісію: Закон України № 1932-IV від 30.06.2004 p. (в редакції від 13.06 .2012 р.) URL: http://zakon2.rada.gov.ua/laws/show/1932-15

6 Про вибори Президента України: Закон України № 474-XIV від 05.03.1999 p. URL: https://zakon.rada.gov.ua/laws/show /474-14

7 Про вибори народних депутатів України: Закон України № 4061-VI від 17.11.2011 р. Відомості Верховної Ради України. 2012. № 10-11. Ст. 73.
} 
можливість розпоряджатися бюджетними коштами, наданими у їі розпорядження для матеріально-технічного та кадрового забезпечення підготовки та проведення виборів. У цьому сенсі більш доцільне формулювання - «виборча комісія має цивільно-правовий статус юридичної особи» (а не «...є юридичною особою») $)^{8}$.

Однак з цим важко погодитись тому, що категорія «юридична особа»є загальновизнаною у теорії держави та права, а також використовується для позначення певної групи суб'єктів конституційного права. Так, право юридичних осіб приватного права на подання конституційної скарги встановлюється чинним Законом України «Про Конституційний Суд України», а Законом України «Про громадські об'єднання» передбачається їхнє право бути засновниками та учасниками громадських спілок. Статус юридичної особи надає можливість бути суб'єктом різних правовідносин, у тому числі трудових, адміністративних, бути позивачем та відповідачем у суді, нести самостійну відповідальність.

Враховуючи викладене, відсутність статусу юридичної особи у дільничних виборчих комісій $\epsilon$ прогалиною у нормативно-правовому регулюванні, що призводить до обмеження кола правовідносин, учасником яких вона може бути, а також до нівелювання їхньої незалежності та можливості неправомірного впливу зі сторони виборчих комісій вищого рівня, що може негативно вплинути на хід та результат виборчого процесу.

Водночас усі виборчі комісії створюються в особливому передбаченому законодавством порядку, а їхній персональний склад формується на підставі підзаконного нормативно-правового акту, зокрема призначення членів Центральної виборчої комісії фіксується у постанові Верховної Ради України. Крім того, виборчі комісії різних рівнів володіють владними повноваженнями та приймають підзаконні нормативно-правові акти, обов'язкові до виконання на території України, що свідчить про необхідність їх віднесення до юридичних осіб публічного права.

Більше того, як чинне виборче законодавство, так і проект Виборчого кодексу України, схвалений у першому читанні, називають виборчі комісії державними органами. Так, Центральна виборча комісія є постійно діючим колегіальним державним органом, який діє на підставі Конституції України, цього Кодексу та інших законів України і наділений повноваженнями щодо організації підготовки і проведення загальнонаціональних та місцевих виборів, всеукраїнського і місцевих референдумів в порядку та в межах, встановлених цим Кодексом та іншими законами України (ч. 1 ст. 51 проекту Виборчого кодексу України). Виборчі комісії є спеціальними державними колегіальними органами, уповноваженими організовувати підготовку та проведення виборів і забезпечувати реалізацію виборчих прав громадян України, додержання та однакове застосування виборчого законодавства України (ч. 1 ст. 52 проекту Виборчого кодексу України)9.

У зв'язку з означеною легальною позицією щодо статусу виборчих комісій для визначення їхньої конституційно-правової природи потрібно зупинитися на питанні їх приналежності до певної гілки (галузі) державної влади.

Н. Богашева та Ю. Ключковський вважають, що «виборчі комісії як органи управління виборчим процесом (чи органи адміністрування виборів) потрібно відносити до галузі виконавчої влади... у цьому випадку поняття «виконавча влада» належить розуміти широко - як сукупність усіх органів державної влади, які здійснюють функцію державного управління (організаційно-розпорядчу, контролю в державному управлінні, регуляторну і т. п.), однак не законодавчу і не судову функції державної влади... природа компетенції таких органів (організаційно-розпорядчих, контрольних чи регуляторних повноважень) фактично зводиться до діяльності з правозастосування, що є основною ознакою виконавчої влади» ${ }^{10}$.

\footnotetext{
8 Богашева Н., Ключковський Ю. Виборчі комісії в системі поділу влади. Науковий вісник Чернівецького університету: Збірник наук. праць. Вип. 641: Правознавство. 2012. С. 116.

9 Проект Виборчого кодексу України № 3112-1 від 02.10.2015p. URL: http://w1.c1.rada.gov.ua/pls/zweb2/webproc4_1 ?pf3511=56671

10 Богашева Н., Ключковський Ю. Виборчі комісії в системі поділу влади // Науковий вісник Чернівецького університету: Збірник наук. праць. Вип. 641: Правознавство. 2012. С. 117-118.
} 
Проте наведена позиція суперечить чинному конституційному законодавству України. Оскільки, відповідно частини першої статті 113 Конституції України «Кабінет Міністрів України $€$ вищим органом у системі органів виконавчої влади» 11 , а уся система органів виконавчої влади підпорядковується уряду. Перераховані вказаними авторами в якості аргументів - організаційно-розпорядчі, контрольні та регуляторні повноваження - належать представникам усіх гілок влади, тому що вони $є$ органами державної влади. Адже саме ці характеристики відрізняють органи державної влади від інших суб'єктів конституційних правовідносин.

Аналізуючи зміст положень Конституції України та чинного виборчого законодавства щодо статусу виборчих комісій, можна дійти висновку, що вони не входять до жодної з гілок (галузей) влади, так як і Президент України.

Однак відносини між вищими і нижчими виборчими комісіями можуть розвиватися тільки на основі форм і методів державного управління. У зв'язку з цим видається вдалою позиція Д. Розенблума, за якою «державне управління - це використання теоретичного надбання менеджменту, політичної науки і правничої сфери та приведення в дію відповідних механізмів для виконання законодавчих, виконавчих і судових управлінських обов'язків при здійсненні регуляторних і обслуговуючих функцій в інтересах усього суспільства чи його окремих сегментів»12. Автор справедливо наголошує на тому, що усі гілки (галузі) державної влади $є$ вторинними, обслуговуючими стосовно до першоджерела - волі народу, а проведення виборів та референдумів $є$ однією з першочергових безпосередніх потреб народу, формами реалізації народовладдя.

Водночас досить цікавою $є$ пропозиція щодо виокремлення окремої гілки (галузі) державної влади - виборчої влади. Так, К. О. Осадчук зауважує, що «суб’єкт виборчої влади - система державних органів, які наділені спеціальними повноваженнями та основною функцією яких є сприяння здійсненню виборчого права громадянами шляхом створення умов для організації та проведення виборів, а також недопущення порушення виборчого законодавства»13. При цьому, оскільки «органи, які безпосередньо здійснюють виборчі процедури (виборчі комісії), фактично не залучені до формування політики у виборчій сфері (це здійснюють інші інституції, зокрема парламент), то говорити про управління виборчим процесом можна лише в контексті здійснення певних управлінських дій у його вузькому розумінні - адміністрування виборчого процесу»14.

Дійсно, змістом діяльності виборчих комісій є управління виборчим процесом, а не формування державної політики у цій сфері, адже парламент затверджує вид виборчої системи у виборчому законодавстві. Однак функціонування системи незалежних виборчих комісій, які здійснюють взаємозв'язок між суспільством і органами публічної влади та забезпечують легітимність, автентичність і чесність виборів, є гарантією встановлення та реалізації справжньої волі Українського народу на виборах та референдумах, тобто невід'ємним елементом механізму народовладдя.

Крім того, про особливе місце виборчих комісій всіх рівнів у державному механізмі України свідчить особливий політично-представницький характер формування їх персонального складу. Так, згідно з ч. 3 ст. 23 Закону України «Про вибори Президента України» подання стосовно кандидатур до складу окружних виборчих комісій (по одній особі до однієї виборчої комісії від одного кандидата) вносяться кандидатами на пост Президента України, які зареєстровані у Центральній виборчій комісії15. Відповідно до ч. 2 ст. 27 Закону України «Про вибори народних депутатів України» суб'єктами подання кандидатур до складу окружних виборчих комісій є: політична партія,

\footnotetext{
11 Конституція України: Закон від 28.06.1996 № 254к/96-BP. База даних Законодавство України / BP України. URL: http://zakon3.rada.gov.ua/laws/show/254к/96-вр/page

12 Rosenbloom D. H. Public Administration: Understanding Management, Politics and Lawin the Public Sector / D. H. Rosenbloom. - New York : Random House, 1986. 6 p.

13 Осадчук К. О. Виборча влада як самостійна гілка державної влади: загальнотеоретичне дослідження : дис. ... канд. юрид. наук : 12.00.01. Одеса, 2016. С. 113.

14 Осадчук К. О. Виборча влада як самостійна гілка державної влади: загальнотеоретичне дослідження : дис. ... канд. юрид. наук : 12.00.01.. Одеса, 2016. С. 117.

15 Про вибори Президента України: Закон України № 474-XIV від 05.03.1999 p. URL: https://zakon.rada.gov.ua/laws/show /474-14
} 
депутатська фракція якої зареєстрована в Апараті Верховної Ради України поточного скликання; політичні партії - суб'єкти виборчого процесу, кандидати у депутати від яких зареєстровані у загальнодержавному окрузі16.

При цьому, участь політичних партій у формуванні виборчих комісій відображає в їх природі представницьку (громадську) складову, яка мінімізується здебільшого включенням до складу виборчих комісій представників тих політичних партій, які вже інституціоналізовані до владної вертикалі представницьких і виконавчих органів державної влади.

Отже, до здійснення публічного адміністрування усього виборчого процесу в Україні залучені й представники громадянського суспільства, що обумовлює складну організаційно-правову форму виборчих комісій як юридичної особи публічного права, самостійного державно-владного інституту з представницьким характером.

Другою ознакою, яка визначає конституційно-правову природу виборчих комісій та їхне місце у державному механізмі України, у тому числі формування окремої гілки (галузі) державної влади - виборчої влади, є незалежність.

Як зазначає Венеційська комісія: «Кодекс належної практики у виборчих справах» ставить вимогу щодо незалежності виборчих комісій у державах з невеликим досвідом організації демократичних виборів. Позитивним зрушенням $\epsilon$ те, що формально незалежні виборчі комісії $\epsilon$ вже звичними у державах Центральної та Східної Європи. Заснування незалежних виборчих комісій можна розглядати як важливий крок до зміцнення безсторонності та нейтральності процесу виборчого адміністрування ${ }^{17}$.

За незалежної моделі управління виборчим процесом займаються переважно постійні органи управління на центральному рівні, що співіснують з тимчасовими, підпорядкованими їм, виборчими комісіями на регіональному чи місцевому рівні (це можна спостерігати на вітчизняному досвіді організації та проведення виборів) ${ }^{18}$. Спираючись на дані дослідження, проведеного Міжнародним інститутом демократії та сприяння виборам у 2006 р. ${ }^{19}$, слід звернути увагу на те, що 3 48 держав Європи 48\% (23 країни) застосовують незалежну модель, 33\% - урядову і 19\% - змішану модель управління виборчим процесом.

Водночас незалежність виборчих комісій як ознака їхньої конституційно-правової природи втілюється у таких характеристиках:

1. Самостійний конституційно-правовий статус, який включає відповідну нормативно-правову регламентацію порядку їх створення, повноважень та відповідальності, що зумовлює необхідність вдосконалення чинного виборчого законодавства.

2. Особливий порядок формування персонального складу виборчих комісій та притягнення до відповідальності, у тому числі їх окремих членів. Так, згідно з положеннями Доповіді про виборче законодавство та виборчу адміністрацію в Європі (CDLAD(2006)018), «навіть якщо членів комісії призначають інші інституції (а не органи виконавчої влади), de facto ці інституції можуть підлягати урядовому контролю. Для уникнення цього ризику можна прийняти три можливі рішення:

а) Важливо, щоб не усі члени комісії призначалися одним органом. «Суміш» інституцій, які залучені до процесу номінації членів комісії, є тепер правилом, що застосовується в Європі у нових демократіях або демократіях, що розвиваються.

\footnotetext{
16 Про вибори народних депутатів України: Закон України № 4061-VI від 17.11.2011 р. Відомості Верховної Ради України. 2012. № 10-11. Ст. 73.

17 Європейський демократичний доробок в галузі виборчого права: Матеріали Венеціанської Комісії, Парламентської Асамблеї, Комітету міністрів, Конгресу місцевих і регіональних влад Ради Європи : пер. з англ. / За ред. Ю. Ключковського. Вид. 2е. Київ, 2009. С. 146.

18 Козодой Л. М. Конституційно-правовий статус суб'єктів виборчого процесу в Україні : дис... канд. юрид. наук : 12.00 .02$. 2006. С. 56.

${ }_{19}$ An Overview of the International IDEAHandbook of Electoral Management Design / A.Wall, A. Ellis, A.Ayoub and others Stockholm : International Institute for Democracyand Electoral Assistance, 2006. P. 4.
} 
b) Вважається корисним, якщо хоча б деякі члени комісії призначаються неполітичними інституціями, які визнаються нейтральними. У деяких державах для такого завдання є придатними спеціальні судові органи. Важливо, що Венеціанська комісія заохочує включення судових органів у процес призначення виборчих комісій, наприклад у Вірменії.

c) Якщо деякі або всі члени комісії призначаються парламентом або політичними партіями, необхідно досягти балансу між проурядовими партіями та партіями опозиції. Однак у деяких державах проурядовим партіям досі надається перевага при створенні комісії. Положення про постійне або розширене членство у виборчих комісіях для включення представників партій часто розглядається як ефективна система гарантування стримувань та противаг у виборчому процесі. Основною ідеєю $є$ те, що одна партія спостерігає за іншою. Проурядові та опозиційні партії, які представлені у виборчій комісії, можуть контролювати одна одну. Тісно пов'язаним із номінацією партійних представників до виборчих комісій $є$ ризик політизації роботи комісії. У таких випадках члени комісії діють більше в інтересах своєї партії, ніж у інтересах електорату. Наслідки можуть бути серйозними: у деяких державах роботі комісії заважали партійні конфлікти та партійне втручання. У таких випадках інтеграція непартійних членів може сприяти деполітизації комісії та її більш професійній діяльності. Більше того, незалежність комісії може бути посилена призначенням членів комісії на фіксований (і достатньо довгий) період часу та заборону їхнього звільнення без обгрунтованих підстав. Відповідно до «Кодексу належної практики у виборчих справах», загалом органи, що призначають членів виборчих комісій, мають бути позбавлені права вільно їх відкликати, оскільки це може спричинити сумніви у їх незалежності» 20.

Незалежні центральні виборчі комісії, сформовані на експертній основі, теоретично найкраще відповідають принципу неупередженості, а незалежні центральні органи управління виборчим процесом, сформовані на партійній основі, можуть мати труднощі з тим, щоб здобути довіру громадськості. Така ситуація може мати місце в країнах, де традиційно система державної служби не позбавлена впливу партій ${ }^{21}$.

Виходячи зі змісту наведених стандартів європейської моделі конституціоналізму, з метою посилення незалежності, неупередженості та кваліфікованості виборчих комісій, можна запропонувати конституційну модернізацію повноважень та порядку формування персонального складу Центральної виборчої комісії як органу, що очолює систему виборчих комісій та комісій з референдуму, забезпечує однакове застосування законодавства України про вибори і референдуми на всій території України шляхом доповнення ст. 71 Конституції України такого змісту:

«Центральна виборча комісія організовує підготовку і проведення виборів до органів державної влади та органів місцевого самоврядування, всеукраїнського і місцевих референдумів, очолює систему виборчих комісій та комісій з референдуму.

До складу Центральної виборчої комісії входять п'ятнадцять членів. Президент України, Верховна Рада України та з'їзд суддів України призначають по п’ять членів Центральної виборчої комісії строком на сім років без права бути призначеним повторно.

Відбір кандидатур на посаду члена Центральної виборчої комісії здійснюється на конкурсних засадах у визначеному законом порядку.

Членом Центральної виборчої комісії може бути громадянин України, який на день призначення досяг тридцяти років, має вищу юридичну освіту, є компетентним, доброчесним та володіє державною мовою.

Член Центральної виборчої комісії не може належати до політичних партій, профспілок, брати участь у будь-якій політичній діяльності, мати представницький мандат, обіймати будь-які

\footnotetext{
20 Європейський демократичний доробок в галузі виборчого права: Матеріали Венеціанської Комісії, Парламентської Асамблеї, Комітету міністрів, Конгресу місцевих і регіональних влад Ради Європи : пер. з англ. / За ред. Ю. Ключковського. Вид. 2е. Київ, 2009. С. 148-149.

21 An Overview of the International IDEAHandbook of Electoral Management Design / A.Wall, A. Ellis, A.Ayoub and others Stockholm : International Institute for Democracyand Electoral Assistance, 2006. P. 23.
} 
інші оплачувані посади, виконувати іншу оплачувану роботу, крім наукової, викладацької чи творчої.

Рішення про звільнення з посади члена Центральної виборчої комісії у випадках, встановлених законом, ухвалюється щонайменше двома третинами від ії̈ конституційного складу».

Пропоновані зміни дозволять не тільки зміцнити незалежність виборчих комісій від інших органів державної влади, зокрема через неможливість звільнення їхніх членів або блокування роботи через не призначення окремих членів у встановлені строки, а й деполітизує та професіоналізує діяльність Центральної виборчої комісії. Вимога доброчесності до членів Центральної виборчої комісії легітимізує їхню діяльність, забезпечить взаємозв'язок з громадськістю.

3. Незалежне коло повноважень, обов'язковість рішень і можливість їх скасування лише у судовому порядку за законною процедурою.

Втілення даної характеристики у діяльності виборчих комісій є частковим, оскільки відповідно до чинних конституційних норм початок виборчого процесу, оновлення складу представницьких органів відбувається за ініціативою інших державних органів. Так, Верховна Рада України призначає вибори Президента України у строки, передбачені цією Конституцією (п. 7 ст. 85 Конституції України), а Президент України призначає позачергові вибори до Верховної Ради України у строки, встановлені цією Конституцією (п. 7 ст. 106 Конституції України) 22.

При цьому, у Конституції України не передбачена відповідальність вказаних суб'єктів за відсутність або несвоєчасність реалізації названих повноважень, що може бути викликана суб'єктивними та об'єктивними факторами, наприклад припинення діяльності коаліції депутатських фракцій у Верховній Раді України та недостатня кількість голосів народних депутатів України, що потрібні дня схвалення відповідної постанови, політичними мотивами тощо. Однак внаслідок таких дій відбувається порушення права громадян України на участь в управлінні державними справами шляхом участі у виборах та референдумах.

Фактично початок виборчого процесу у зв'язку із завершенням строку повноважень представницьких органів державної влади та місцевого самоврядування - це організаційне рішення, воно повинно прийматись саме Центральною виборчою комісією, що вимагає відповідних конституційних змін.

Крім того, доцільно викласти ч. 2 ст. 72 Конституції України у такій редакції: «Всеукраїнський референдум за народною ініціативою проголошується Центральною виборчою комісією на вимогу не менш як трьох мільйонів громадян України, які мають право голосу, за умови, що підписи щодо призначення референдуму зібрано не менш як у двох третинах областей і не менш як по сто тисяч підписів у кожній області».

Таким чином, задоволення народної ініціативи щодо вирішення певного загальнонаціонального питання на всеукраїнському референдумі та обов'язкова реалізація його результату не буде залежати від бажання чи небажання Президента України його проголошувати через особисті мотиви, а також не буде затягування процесу його проведення.

4. Матеріально-фінансова самостійність забезпечена постійним безпосереднім фінансуванням 3 бюджету на основі спеціально виділених і закріплених в бюджеті коштів дозволяє ефективно працювати Центральній виборчій комісії у міжвиборчий період над питаннями роз'яснення виборчого законодавства України, інформування населення про їх виборчі права, а також навчання потенційних членів інших рівнів виборчих комісій.

Третьою ознакою, яка визначає конституційно-правову природу виборчих комісій, $\epsilon$ їх колегіальність.

Європейське виборче право сприймає колегіальність у роботі комісій як аксіому. Адже європейські експерти вже давно наголошують, що прийняття рішень виборчими комісія має відбуватись не простою більшістю голосів - воно має грунтуватись на консенсусі. Зокрема, у Кодексі належної практики у виборчих справах відмічалось побажання, щоб виборчі комісії ухвалювали

22 Конституція України: Закон від 28.06.1996 № 254к/96-BP. База даних Законодавство України / BP України. URL: http://zakon3.rada.gov.ua/laws/show/254к/96-вр/page 
рішення кваліфікованою більшістю голосів або консенсусом²3. 3 цього ж приводу у доповіді Венеційської комісії про виборче законодавство та виборчу адміністрацію в Європі відзначається, що діяльність комісії та її рішення повинні бути орієнтованими на консенсус ${ }^{24}$. «одекс належної практики у виборчих справах» вказує, що мало б сенс прийняття рішень кваліфікованою (2/3) більшістю для того, щоб сприяти дебатам між партіями більшості та меншості. Бажаним $\epsilon$ досягнення рішень шляхом консенсусу (CDL-AD (2002) 023rev, абз. 80). У різних випадках Венеційська комісія рекомендувала запровадження вищого кворуму та/або кваліфікованої більшості для підвищення залученості у рішеннях виборчих комісій (CDL-AD (2003) 021, абз. 12; CDL-AD (2004) 016 rev, абз. 12).

Аналіз виборчих законів дозволяє говорити про уніфікований підхід законодавця у питанні визначення статусу виборчих комісій як колегіальних органів, рішення яких приймається відкритим голосуванням більшістю голосів від складу комісії. Тому для його приведення ознаки колегіальності виборчих комісій у відповідність зі стандартами європейської моделі конституціоналізму доцільно підвищити кворум прийняття рішень на рівні Центральної виборчої комісії до кваліфікованої більшості від іiї законодавчого (можливо, в майбутньому конституційного) складу.

Четвертою ознакою, яка визначає конституційно-правову природу виборчих комісій є їх компетентність.

Компетентність у даному випадку - це передусім спроможність виборчих комісій правильно, у відповідності з чинним законодавством, організувати вибори та референдуми, вирішувати конфліктні питання, надавати якісну допомогу в реалізації виборчих прав громадян України.

К. Афанасьєв пропонує вважати члена виборчої комісії тимчасовим державним службовцем із певним обсягом його компетенції 25 , оскільки його статус тяжіє до статусу державного службовця. Не зупиняючись на відмінностях між статусом державного службовця та члена виборчої комісії, крім Центральної виборчої комісії, слід наголосити на тому, що незважаючи, як правило, на відсутність трудових відносин між виборчою комісією та її членом, його діяльність підпорядкована нормам чинного виборчого законодавства та рішенням виборчих комісій.

Передусім члени виборчих комісій мають бути обізнані у поточному законодавстві та мати необхідні навички для управління виборами, аби не допустити у своїй діяльності порушень. Законодавство більшості розвинених країн встановлює особливі кваліфікаційні вимоги до членів виборчих комісій. Зокрема, кандидат на посаду голови комісії має бути суддею у таких країнах, як Македонія, Польща, Румунія. Обов'язковим є включення до складу комісій осіб у відповідній кількості, що мають вищу юридичну освіту, які своєю підготовкою сприятимуть покращенню ефективності діяльності комісії та зростанню відповідальності її членів за виконувану ними роботу (Румунія, Литва, Німеччина та ін.) ${ }^{26}$.

Венеційська комісія рекомендує навчальні курси, особливо для членів комісій нижчого рівня. «Члени виборчих комісій повинні отримати загальне тренування на всіх рівнях виборчої адміністрації. Таке тренування повинно бути також доступним для членів комісій, що призначені політичними партіями» (CDL-AD (2002) 023rev, абз. 84). Програми підготовки для членів виборчих комісій є тим часом спільними для усіх нових демократій в Європі. Існує одностайна думка, що рання та грунтовна підготовка суттєво підвищить професіоналізм та довіру до виборчої

\footnotetext{
23 Європейський демократичний доробок в галузі виборчого права: Матеріали Венеціанської Комісії, Парламентської Асамблеї, Комітету міністрів, Конгресу місцевих і регіональних влад Ради Європи : пер. з англ. / За ред. Ю. Ключковського. Вид. 2е. Київ, 2009. С. 57.

24 Європейський демократичний доробок в галузі виборчого права: Матеріали Венеціанської Комісії, Парламентської Асамблеї, Комітету міністрів, Конгресу місцевих і регіональних влад Ради Європи : пер. з англ. / За ред. Ю. Ключковського. Вид. 2е. Київ, 2009. С. 89-90.

25 Афанасьєв К. Адміністративна відповідальність за порушення виборчих прав громадян України: окремі проблемні питання. Вибори та демократія. 2006. № 3 (9). С. 60-65.

26 Виборче законодавство: українська практика, міжнародний досвід та шляхи реформування / за заг. ред. Є. В. Радченка. К. : Факт, 2003. С. 70-72.
} 
адміністрації. Було навіть рекомендовано, щоб відвідування тренінгів було визначене обов'язковим за законом (CG/BUR (11) 122rev). Далекоглядні пропозиції вимагають, щоб членами комісії могли стати лише особи, які пройшли підготовку та екзамен 27.

3 огляду на це, I. В. Тимошенко вважає доцільним встановити в українському законодавстві не лише обов'язкову вказівку наявності спеціального освіти чи досвіду і підготовки для роботи у виборчих комісіях, а й вимогу мати обов'язково вищу юридичну освіту, принаймні певній кількості членів комісій - керівного складу, або включати до її складу осіб, які є суддями, працівниками системи Міністерства юстиції чи Міністерства внутрішніх справ ${ }^{28}$.

Можна погодитись з М. Бучиним у тому, що потрібно передбачити «освітній та віковий цензи для членів комісій i, особливо, для його керівного складу... необхідне проведення професійного навчання для усіх членів комісій, а також введення до її складу компетентних людей, професійна діяльність яких є дотичною до виборів» 29.

Водночас, крім перерахованих вимог для забезпечення компетентності виборчих комісій спеціальне навчання або юридична освіта членів виборчих комісій, практичні навички здійснення виборчого процесу, слід закріпити необхідність володіння членами виборчих комісій державною мовою та мовою громадян України, які належать до національних меншин в межах територій їх компактного проживання.

П’ятою ознакою, яка визначає конституційно-правову природу виборчих комісій, $\epsilon$ їх прозорість та відкритість, яка проявляється у можливості бути присутностніми на їх засіданнях кандидатів (їх довірених осіб), офіційних спостерігачів, представників засобів масової інформації, а також надання для вільного ознайомлення рішень всіх рівнів виборчих комісій.

У висновку можна зазначити, що концепт конституційно-правової природи виборчих комісій за стандартами європейської моделі конституціоналізму розкривається у їх сутнісних ознаках: 1) організаційно-правова форма юридичної особи публічного права, самостійного державно-владного інституту з представницьким характером, що може формувати виборчу владу, та тимчасовим характером функціонування для окружних (територіальних) і дільничних виборчих комісій;

2) незалежність, що проявляється в особливому порядку формування персонального складу різних рівнів виборчих комісій та достроковому припиненні повноважень окремих їх членів, а також в наявності самостійних владних повноважень і матеріально-фінансової самостійності;

3) колегіальність, яка втілюється в порядку прийняття рішень виборчими комісіями;

4) компетентність - полягає у особливих юридичних знаннях та практичних навичках здійснення виборчого процесу;

5) прозорість та відкритість.

Перспективними напрямами розвитку функціонування виборчих комісій в України є модернізація конституційно-правового статусу як Центральної виборчої комісії шляхом посилення іiі незалежності та розширення ії повноважень з метою формування окремої гілки (галузі) виборчої влади, так і вдосконалення конституційно-правового регулювання практичної діяльності інших виборчих комісій.

\footnotetext{
27 Європейський демократичний доробок в галузі виборчого права: Матеріали Венеціанської Комісії, Парламентської Асамблеї, Комітету міністрів, Конгресу місцевих і регіональних влад Ради Європи : пер. з англ. / За ред. Ю. Ключковського. Вид. 2е. Київ, 2009. С. 152.

28 Тимошенко I. В. Проблемні питання визначення статусу виборчих комісій та їх членів як суб’єктів юридичної відповідальності. Правовий вісник Української академії банківської справи. 2008. № 1. С. 36-41.

29 Бучин М. Правовий статус виборчих комісій в Україні. Humanitarian Vision. 2016. Volume 2, number 2. P. 1-6.
} 


\section{Список використаних джерел}

\section{Бібліографія:}

1. An Overview of the International IDEAHandbook of Electoral Management Design / A.Wall, A. Ellis, A.Ayoub and others Stockholm : International Institute for Democracyand Electoral Assistance, 2006. 391 p.

2. Rosenbloom D. H. Public Administration: Understanding Management, Politics and Lawin the Public Sector / D. H. Rosenbloom. - New York: Random House, 1986. 360 p.

3. Афанасьєв К. Адміністративна відповідальність за порушення виборчих прав громадян України: окремі проблемні питання. Вибори та демократія. 2006. № 3 (9). С. 60-65.

4. Богашева Н., Ключковський Ю. Виборчі комісії в системі поділу влади. Науковий вісник Чернівецького університету: Збірник наук. праць. Вип. 641: Правознавство. 2012. С. 113-120.

5. Бориславська О.М. Вплив Ради Європи та Європейського Союзу на формування європейської (континентальної) моделі конституціоналізму. Правова держава.2016. № 24. С. 40-49.

6. Бучин М. Правовий статус виборчих комісій в Україні. Humanitarian Vision. 2016. Volume 2, number 2. P. 1-6.

7. Виборче законодавство: українська практика, міжнародний досвід та шляхи реформування / за заг. ред. Є.В. Радченка. К. : Факт, 2003. 258 с.

8. Європейський демократичний доробок в галузі виборчого права: Матеріали Венеціанської Комісії, Парламентської Асамблеї, Комітету міністрів, Конгресу місцевих і регіональних влад Ради Європи : пер. з англ. / За ред. Ю. Ключковського. Вид. 2е. Київ, 2009. 340 с.

9. Козодой Л.М. Конституційно-правовий статус суб'єктів виборчого процесу в Україні : дис... канд. юрид. наук : 12.00.02. 2006. $228 \mathrm{c.}$

10. Осадчук К.О. Виборча влада як самостійна гілка державної влади: загальнотеоретичне дослідження : дис. ... канд. юрид. наук : 12.00.01. Одеса, 2016. 213 с.

11. Паращевіна О.А. Деякі проблеми класифікації колективних суб’єктів права // Актуальні проблеми держави і права. 2011. № 62. С. 651-658.

12. Тимошенко І. В. Проблемні питання визначення статусу виборчих комісій та їх членів як суб'єктів юридичної відповідальності. Правовий вісник Української академії банківської справи. 2008. № 1. С. 36-41.

13. Яворський В.Д. Суб’єкти виборчого права України: поняття, ознаки та їх види. Державне будівництво та місцеве самоврядування. 2002. № 4. С. 45-50.

\section{Перелік юридичних документів:}

1. Конституція України: Закон від 28.06.1996 № 254к/96-BP. База даних Законодавство України / BP України. URL: http://zakon3.rada.gov.ua/laws/show/254к/96-вр/page

2. Про вибори народних депутатів України: Закон України № 4061-VI від 17.11.2011 р. Відомості Верховної Ради України. 2012. № 10-11. Ст. 73.

3. Проект Виборчого кодексу України № 3112-1 від 02.10.2015p. URL:

http://w1.c1.rada.gov.ua/pls/zweb2/webproc4_1?pf3511=56671

4. Про вибори Президента України: Закон України № 474-XIV від 05.03.1999 p. URL: https://zakon.rada.gov.ua/laws/show/474-14

5. Про Центральну виборчу комісію: Закон України № 1932-IV від 30.06.2004 р. (в редакції від 13.06.2012 р.) URL: http://zakon2.rada.gov.ua/laws/show/1932-15

\section{$\underline{\text { References }}$}

\section{Bibliography:}

1. An Overview of the International IDEAHandbook of Electoral Management Design / A.Wall, A. Ellis, A.Ayoub and others Stockholm : International Institute for Democracyand Electoral Assistance, 2006. $391 \mathrm{p}$.

2. Rosenbloom D. H. Public Administration: Understanding Management, Politics and Lawin the Public Sector / D. H. Rosenbloom. New York : Random House, 1986. 360 p.

3. Afanasev K. Administratyvna vidpovidalnist za porushennja vyborchih prav gromadjan Ukrayiny. Vybory ta demokratija. 2006. № 3 (9). S. 60-65.

4. Bohasheva N., Klyuchkovskyj YU. Vyborchi komisii v systemi podilu vlady. Naukovyj visnek Cherniveckogo universytetu: Zbirnyk nauk. prac. Vyp. 641: Pravoznavstvo. 2012. S. 113-120

5. Boryalavskaja O.M. Vplyv Rady Evropy ta Evropejskogo Soyuzu na formuvannja evropejskoi (kontynentalnoi) modeli konstytuzionalizmu. Pravova derzhava. 2016. № 24. S. 40-49.

6. Buchin M. Pravovyj status vyborchih komisii v Ukraini. Humanitarian Vision. 2016. Volume 2, number 2. P. 1-6. 
7. Evropejskyj demokratuchynyj dorobok v galuzi vuborchogo prava: Materialy Venecianskoi Komisii, Parlamentskoi Asamblei, Komitetu ministriv, Kongresu miscevyh i regionalnyh vlad Rady Evropy: per. z angl. / Za red. YU. Klyuchkovskogo. Vyd. 2e. K., 2009. 340 s.

8. Javorskij V.D. Sub'ekty vyborchogo prava Ukrainy: ponjattja, oznaky ta ih vydy Derzhavne budivnyctvo ta misceve samovrjaduvannja. 2002. № 4. S. 45-50.

9. Kozodoj L.M. Konstytuciyno-pravovyj status sub'ektiv vyborchogo procesu v Ukraini : dys. kand. yuryd. nauk. : 12.00 .02 . 2006. $228 \mathrm{~s}$.

10. Osadchuk K.O. Vyborcha vlada jak samostijna gilka derzhavnoi vlady: zagalnoteoretychne doslidzhenja : dys. kand. yuryd. nauk. : 12.00.02. 2016. $213 \mathrm{~s}$.

11. Parashhevina O.A. Dejaki problem klasyfikaciji kolektuvnuh sub'ektiv prava. Aкtualni problemy derzhavy i prava. 2011. № 62. S. 651-658.

12. Tymoshenko I.V. Problemni pytanja vyznachenja statusu vyborchih komisii ta ih chleniv jak sub'ektiv yuridychnoi vidpovidalnosti Pravovyj visnyk Ukrainskoi akademii bankivskoi spravy. 2008. № 1. S. 36-41.

13. Vyborche zakonodavstvo: ukrainskaja praktika, mizhnarodnoyi dosvid ta shlahy reformuvanja / za zag. red. E.V. Radchrnko . K.: Fakt, 2003. 258 c.

\section{List of legal documents:}

1. Konstytuciya Ukrayiny: Zakon vid 28.06.1996 № 254k/96-VR. Baza danyx Zakonodavstvo Ukrayiny /VR Ukrayiny. URL: http://zakon3.rada.gov.ua/laws/show/254к/96-вр/page

2. Proekt vyborchoho kodeksu №3112-1 vid 02.10.2015 URL: http://w1.c1.rada.gov.ua/pls/zweb2/webproc4_1?pf3511=56671

3. Pro Tsentralnu vyborchu komisiiu: Zakon Ukrainy vid 17 hrudnia 1997 r. Baza danyx Zakonodavstvo Ukrayiny /VR Ukrayiny. URL: http://www.zakon1. rada.gov.ua/ cgi bin/laws/ main.cgi?nreg=733\%2F97 \%E2\%F0

4. Pro vybory narodnykh deputativ Ukrainy: Zakon Ukrainy vid 18.11.2011 r. // Vidomosti Verkhovnoi Rady. 2012. No. 1011. S. 73.

5. Pro vybory Prezydenta Ukrainy: Zakon Ukrainy vid 5 bereznia 1999 r. URL https://zakon.rada.gov.ua/laws/show/474-14 